\title{
Processing samples of benthic marine diatoms from Mediterranean oligotrophic areas
}

Simon Vermeulen*, Gilles Lepoint, Sylvie Gobert

\begin{abstract}
The processing of benthic diatoms is tedious and involves several potentially damaging steps for cells. Although the preservation of siliceous frustules is of paramount importance in the implementation of biotic indices, only few studies quantified treatment-induced cell losses. We assumed that commonly used treatments may lead to mechanical (centrifugation, sedimentation, boiling, sonication and mounting in Naphrax) and chemical (cold $\mathrm{H}_{2} \mathrm{O}_{2}$ digestion) damages on diatoms. We analysed the potential adverse effects of these treatments and the cleaning efficiency of $\mathrm{H}_{2} \mathrm{O}_{2}$ and incineration in order to find out the most suitable technique to process lightly silicified Mediterranean populations. Results showed that successive resuspensions of material after each concentration treatment (sedimentation and centrifugation) and low speed centrifugation did not alter the physical integrity of frustules. In contrast, boiling and sonication exhibited adverse effects especially on the preservation of large frustules and Naphrax mounting proved to be the most damaging step whatever the size of diatoms. For cleaning treatments, incineration provided the most satisfactory results and acted on a non-selective way as opposed to hydrogen peroxide which led to either a large number of non-cleaned frustules or dissolved valves. Our recommendations for processing samples of lightly silicified Mediterranean benthic diatoms include the use of low speed centrifugations, dehydration at room temperature, incineration and dry mounting.
\end{abstract}

Key words : Bacillariophyta, Methods, Cell losses, Cleaning techniques, Silicification

\section{Introduction}

Benthic diatoms are routinely used in the monitoring of freshwater quality in European countries (Kelly et al. 1998, Prygiel et al. 1999) and become increasingly studied in many other parts of the world (Pan et al. 2000, Gómez and Licursi 2001, Chessman et al. 2007, Taylor et al. 2007). The implementation of biotic indices based on the species-specific ecological tolerance to pollution allowed to assess the quality of areas subjected to anthropogenic discharges of organic matters (Prygiel and Coste 1993), nutrients (Dela-Cruz et al. 2006, Kelly 2003), and trace elements (Gurrieri 1998). In contrast, benthic marine diatoms received considerably less

\footnotetext{
* S. Vermeulen $(\bowtie)$, G. Lepoint, S. Gobert MARE Centre, Laboratory of Oceanology, University of Liège, Sart Tilman B6c, 4000 Liège, Belgium e-mail: sdt.vermeulen@gmail.com
} 
The final publication is available at www.springerlink.com, Journal of Applied Phycology

attention compared to their freshwater counterparts and most studies were conducted on brackish soft-bottom populations (i.e. under strong influences of freshwater inputs) (Underwood et al. 1998, Muniz et al. 2011). The available literature dealing with the composition of epilithic assemblages grown on natural (Hendey 1964, MacLulich 1987) or artificial substrates in coastal waters (Hillebrand and Sommer 2000, Brandini et al. 2001, Totti et al. 2007) remains scarce mainly because of the existence of methodological difficulties in the processing of samples and of a lack of taxonomic knowledge regarding marine populations (Agatz et al. 1999).

The bioindicator status of benthic freshwater diatoms relies on the taxonomic analysis of populations which is based upon the fine morphological details of their siliceous frustules (e.g. Hasle and Fryxell 1970). Cell contents as well as other organic items have to be removed to insure the best possible visual quality of samples. The sample processing generally involves four main steps including two cycles of at least three washes respectively occurring before (preservative removal) and after the cleaning step (discarding chemicals) (Battarbee et al. 2001). Finally a subsample is embedded in a high refractive index resin and identification of diatoms is routinely performed under a light microscope. The way to perform each of these steps differs largely according to authors but samples usually undergo centrifugations (washes) and boiling in $\mathrm{H}_{2} \mathrm{O}_{2}$ or in concentrated $\mathrm{H}_{2} \mathrm{SO}_{4}$ and/or $\mathrm{HNO}_{3}$ (e.g. von Stosch method) as these methods are considered as time-efficient (Round et al. 1990, Hasle et al. 1996, Kelly et al. 1998). However, due to their low flexibility and their variable silicification, frustules may experience mechanical stress at each step of the process resulting in cumulative losses of cells (Pickett-Heaps 1998). For example, vigorous centrifugations and sonication respectively used in the washing and in the homogenisation of samples are known to potentially involve cell breakages (Battarbee et al. 2001, Abrantes et al. 2005). Diatoms also differently withstand the cleaning step with delicate forms being more subjected to dissolution than heavily silicified frustules (Hart 1957, Hendey 1964, Flower 1993). Since fragments, broken and dissolved cells are usually discarded from counts (USGS 1987, Taylor et al. 2005), such losses may hamper the bioindicator potential of diatoms and/or increase the counting effort for analysts (Ryves et al. 2006, Blanco et al. 2008). However, the quantification of treatment-induced losses is particularly scarce in the literature and until now only the adverse effects of centrifugation were investigated for freshwater epilithic (Owen et al. 1978, Blanco et al. 2008) and fossil diatoms (Flower 1993, Abrantes et al. 2005).

Marine diatoms are likely to be very sensitive to usual treatments since it has been shown that their silica content per unit of biovolume was on average an order of magnitude lesser than that of freshwater populations because of the lower availability of silicic acid and of the interference of salinity in silica fixation (Conley et al. 1989). A nutrient limitation (N and P) also indirectly explains a low silicification of frustules because of a slower growth 
The final publication is available at www.springerlink.com, Journal of Applied Phycology

rate of diatoms compared to those living in nutrient replete conditions (Martin-Jézéquel et al. 2000). The Mediterranean Sea naturally combines these features being oligotrophic and having a high salinity. To our knowledge, only few works dealt with the composition of diatom populations grown on artificial substrates in the Northern Adriatic Sea (Munda 2005, Totti et al. 2007) but this region is heavily urbanized and receives high anthropogenic nutrient loads which likely promoted the growth of more silicified taxa compared to pristine areas. The study of Mediterranean benthic diatoms from undisturbed areas is required and implies to find out the most suitable sample processing technique before assessing their potential as early indicators of pollution.

This work focused on the mechanical and chemical stresses to which samples are exposed to during the most commonly used procedures and provides the first stepwise quantification of cell losses among populations of benthic marine diatoms grown on glass slides from an oligotrophic Mediterranean area.

\section{Materials and Methods}

Study site and sampling

The sampling was carried out in July 2008 in the vicinity of the STAtion de REcherches Sous-marines et Océanographiques (STARESO - University of Liège, $8^{\circ} 43^{\prime} \mathrm{E}, 42^{\circ} 34^{\prime} \mathrm{N}$ ) located in the Revellata Bay (Corsica, France). This coastal area is typically oligotrophic and is only slightly and seasonally influenced by anthropogenic nutrient discharges, river flows or freshwater runoffs (see Vermeulen et al. 2011 for further details on study site). Over study time, salinity ranged from 37.8 to 38.1 and average nutrient concentrations were 0.09 $\pm 0.05 \mu \mathrm{M} \mathrm{NO}_{3}{ }^{-}, 0.08 \pm 0.01 \mu \mathrm{M} \mathrm{NH}_{4}{ }^{+},<0.01 \mu \mathrm{M} \mathrm{PO}_{4}{ }^{3-}$ and $0.95 \pm 0.09 \mu \mathrm{M} \mathrm{Si}(\mathrm{n}=8)$.

Three samples of algal biofilms grown for 24 days at $1 \mathrm{~m}$ depth on glass slides were collected using a razor blade. They were preserved in a solution (3\%) of formaldehyde - filtered seawater (Millipore, acetate cellulose $0.22 \mu \mathrm{m})$. Because of the occurrence of filamentous macroalgae on slides, samples were homogenised by gentle sieving through nylon nets (mesh sizes 500 and $300 \mu \mathrm{m}$ ) with MilliQ water and filtrates were allowed to settle for at least 5 days in $400 \mathrm{~mL}$ Pyrex beakers. The supernatant was then siphoned off with a syringe device and the volume of samples was adapted to obtain a density of about 3 frustules per microscopic field (objective x 40 ). Most diatoms occurring in samples were lightly silicified pennate forms. Mean density estimates ( \pm SD) were $2245 \pm 118$ cells $\mathrm{mm}^{-2}$ and the proportion of empty frustules ranged from 2 to $5 \%$ according to samples. The occurrence of detritus and calcareous material was negligible (Vermeulen unpubl. data). 


\section{Assessment of mechanical stress}

Five common treatments used in the processing of samples were identified in the literature and assessed for the potential mechanical stress they exert on diatoms (Fig. 1).

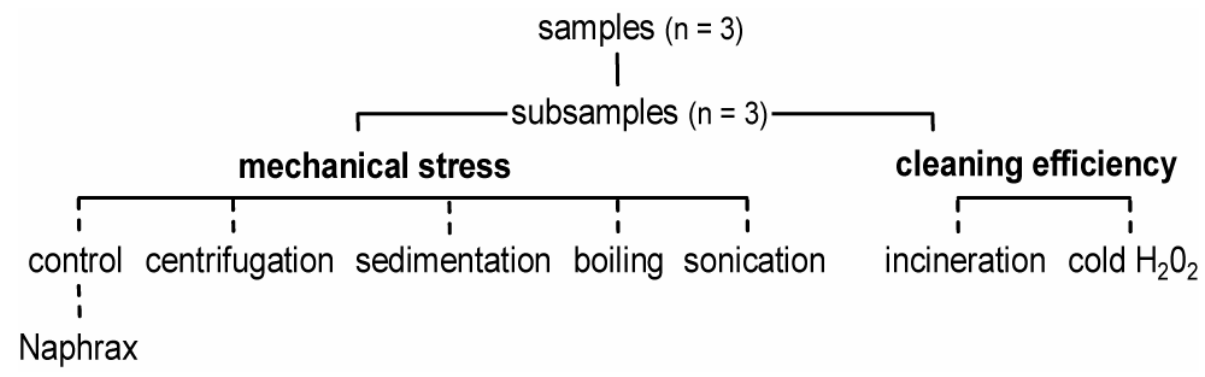

Fig. 1 Stepwise assessment of mechanical stress and cleaning efficiency for samples of Mediterranean benthic diatoms.

For each sample, three- $2 \mathrm{~mL}$ subsamples were exposed to these treatments and we paid attention to select the gentlest methods reported in the literature (Tab 1). Each subsample was gently stirred and a $30 \mu \mathrm{L}$ aliquot was mounted under cover slip ( $\left.\mathrm{N}^{\circ} 0\right)$ with a drop of glycerine pending for analyses. A set of control subsamples which were not exposed to any stress was first analysed. The two washing steps were successively performed 6 times to simulate the stress undergone by samples before and just after the cleaning step. After each centrifugation (2000 rpm, $580 \mathrm{x}$ g for $30 \mathrm{~min}$ ) and sedimentation time $(24 \mathrm{~h})$, the supernatant was siphoned off and the remaining pellet was resuspended in MQ water. The boiling step in MQ water was carried out on a hot plate set at $100{ }^{\circ} \mathrm{C}$ for 15 minutes (AFNOR 2003). This procedure is used to increase the oxidising power of chemicals during the cleaning step. The sonication is used to dislodge frustules from particular substrates (Sabater et al. 1998), to homogenise samples and/or to dissociate valves from frustules (Battarbee et al. 2001). This step was performed with an ultrasonic bath (Sonorex RK156BH, $35 \mathrm{KHz}$ ) during 2 x 2 min. Permanent mounts were made using Naphrax, the most commonly used high refractive index medium (R.I. 1.73, Brunel Microscope Ltd, UK). Aliquots from control subsamples were first dehydrated at room temperature on cover slips to allow a random settlement of frustules in valvar view (Blanco et al. 2008) and were then placed on a Naphrax drop. Preparations were warmed on a hot plate set at $120^{\circ} \mathrm{C}$ for 5 min and some slight pressures were applied to withdraw air bubbles that could have hidden frustules (Taylor et al. 2005). 


\begin{tabular}{|c|c|c|c|c|c|}
\hline Study feature & Concentration & Sonication & Cleaning & Mounting & Sources \\
\hline Spain, fw, Mtd & Ce, 2500 rpm, 5 min, x 3 ac & & $\mathrm{H}_{2} \mathrm{O}_{2}, 90^{\circ} \mathrm{C}, 6-12 \mathrm{~h}$ & Naphrax & Blanco et al. 2008 \\
\hline Baltic sea, sw & Se, $\times 4$ ac & & $\mathrm{H}_{2} \mathrm{O}_{2}, \mathrm{~K}_{2} \mathrm{Cr}_{2} \mathrm{O}_{7}, \mathrm{~cd}$ & Naphrax & Busse and Snoeijs 2002 \\
\hline Mtd & Ce, ni rpm, x 8 ac & & $\mathrm{H}_{2} \mathrm{SO}_{4}, \mathrm{KMnO}_{4}, \mathrm{C}_{2} \mathrm{H}_{2} \mathrm{O}_{4}, \mathrm{~cd}$ & Various & Hasle and Fryxell 1970 \\
\hline Mtd & Se, $x 5 \mathrm{ac}$ & $2 \mathrm{~min}, 20 \mathrm{Khz}$ & $\mathrm{HNO}_{3}$, blg 5 min & Naphrax & McBride 1988 \\
\hline Uruguay, sw & Ce, ni rpm, x 10 & & $\mathrm{H}_{2} \mathrm{O}_{2}$, blg $4 \mathrm{~h}$ & Entellan & Muniz et al. 2011 \\
\hline USA, fw & ni & $2 \times 2 \min , \mathrm{ni}$ & acid cleaning, ni & ni & Sabater et al. 1998 \\
\hline S - Africa, fw, Mtd & $\mathrm{Ce}, 2500 \mathrm{rpm}, 10 \mathrm{~min}, \mathrm{x} 8$ & & $\begin{array}{l}\mathrm{H}_{2} \mathrm{O}_{2}, 90{ }^{\circ} \mathrm{C}, 1-3 \mathrm{~h} \\
\mathrm{H}_{2} \mathrm{O}_{2}, \mathrm{~cd}, 4 \text { days at least }\end{array}$ & Various & Taylor et al. 2005 \\
\hline Adriatic sea, sw & Ce, 3000 rpm, 10 min, x 6 & & $\mathrm{HNO}_{3}, \mathrm{H}_{2} \mathrm{SO}_{4}$, blg $3 \mathrm{~min}$ & gold (SEM) & Totti et al. 2007 \\
\hline $\begin{array}{l}\text { Mediterranean sea, } \\
\text { Corsica, sw, Mtd }\end{array}$ & $\mathrm{Se}, \mathrm{Ce}, 2000 \mathrm{rpm}, 30 \mathrm{~min}, \mathrm{x} 6$ & $2 \times 2 \mathrm{~min}, 35 \mathrm{Khz}$ & $\begin{array}{l}\text { incineration } 500^{\circ} \mathrm{C}, 30 \mathrm{~min} \text {, } \\
\mathrm{H}_{2} \mathrm{O}_{2} \text {, cd } 4 \text { days, blg } 15 \mathrm{~min}\end{array}$ & Naphrax, dry & Present study \\
\hline
\end{tabular}

Table 1 Examples of common techniques for processing benthic diatom samples. fw freshwater, sw seawater, Mtd methodological works, total number of Ce centrifugations and Se sedimentations except when ac after cleaning step only mentioned, cd cold, blg boiling digestions, gaps indicate "not used" and.ni no available information

\section{Cleaning efficiency of diatoms}

We chose two soft cleaning treatments (Fig. 1, Tab 1). Three aliquots per subsample were dehydrated at room temperature and incinerated at $500^{\circ} \mathrm{C}$ in a muffle furnace during 30 minutes (USGS 1987). Hydrogen peroxyde (30\%) was added to 3 subsamples per sample as 2:1 in v/v. The cold oxidation lasted 96 h (e.g. Hillebrand \& Sommer 2000, Taylor et al. 2005) and subsamples were centrifuged three times and dehydrated as previously described. Cover slips were mounted dry (i.e. without Naphrax) (Hendey 1964, Round et al. 1990) and corners were fixed with few drops of Eukitt ${ }^{\circledR}$ (Fluka, BioChemika).

\section{Counts}

Aliquots were observed under an interferential phase contrast light microscope (Olympus BX 50). The measured variables in relation with mechanical stress were: intact and broken frustules and valves, contorted frustules, and fragments (unidentifiable objects either frustules or valves). Separate counts were performed as follows according to the length of diatoms and fragments: 1) diatoms $>100 \mu \mathrm{m}$ counted over 25 microscopic fields at objective x10 and 2) < 100 diatoms counted over 40 fields of view at 40 x objective. The cleaning efficiency of diatoms was assessed according to 4 classes as follows: good (well cleaned with all identification features), medium and bad (respectively partially and not cleaned of organic content), and dissolved (only showing external margins preventing species identification). Additionally, broken frustules and valves as well as fragments were enumerated. Counts were performed on 70 fields of view at objective x 100 using immersion oil. 


\section{Statistics}

As frustules dominated our samples, the number of valves was converted into frustules as follows (number of frustules $+($ number of valves / 2)). Statistical analyses were conducted on absolute values of fragments and on percentages of frustules measured for each mechanical stress variable and each cleaning efficiency class calculated from the total number of frustules. As data did not fit assumptions of normality and variance homogeneity, we performed non-parametric tests. The Kruskal-Wallis ANOVA was used to compare between samples for each variable and each treatment and Wilcoxon tests allowed comparisons between size classes and between cleaning treatments. Regression analysis was carried out to examine the relationship between the numbers of fragments and valves for cleaning treatments. Multivariate analyses were also performed on data from the mechanical stress assessment to test the null hypothesis that there was no difference between treatments for each of the diatom size classes. Bray-Curtis similarity matrices were constructed from untransformed data from all variables together and one-way Analyses of similarity (ANOSIM) were performed on these matrices along with non Metric multi-Dimensional Scaling (nMDS) graphical ordinations. The stress value provided with nMDS refers to the goodness of fit of a matrix in the bidimensional space with values below 0.1 showing a good representation. The R statistics output of ANOSIM indicate the separation degree between groups of treatments with values close to 0 and 1 respectively showing complete similarity and dissimilarity (Clarke and Gorley 2006). Significance of statistical tests was assumed at $P<0.05$. Univariate and multivariate analyses were respectively completed using Statistica v.9 and Primer v.6 softwares.

\section{Results}

All variables together, the average total number $( \pm$ SD) of counted frustules per subsamples was $93.2 \pm 20.6$ and $92.0 \pm 20.7$ respectively for $<100 \mu \mathrm{m}$ and $>100 \mu \mathrm{m}$ diatoms and $155.0 \pm 23.9$ for the cleaning treatments. Samples did not differ significantly within a treatment type both for the assessment of mechanical stress and of the cleaning efficiency. The values of broken frustules and fragments highly differed according to treatments for each size class $(P<0.0001$, Fig. 2). 
a)

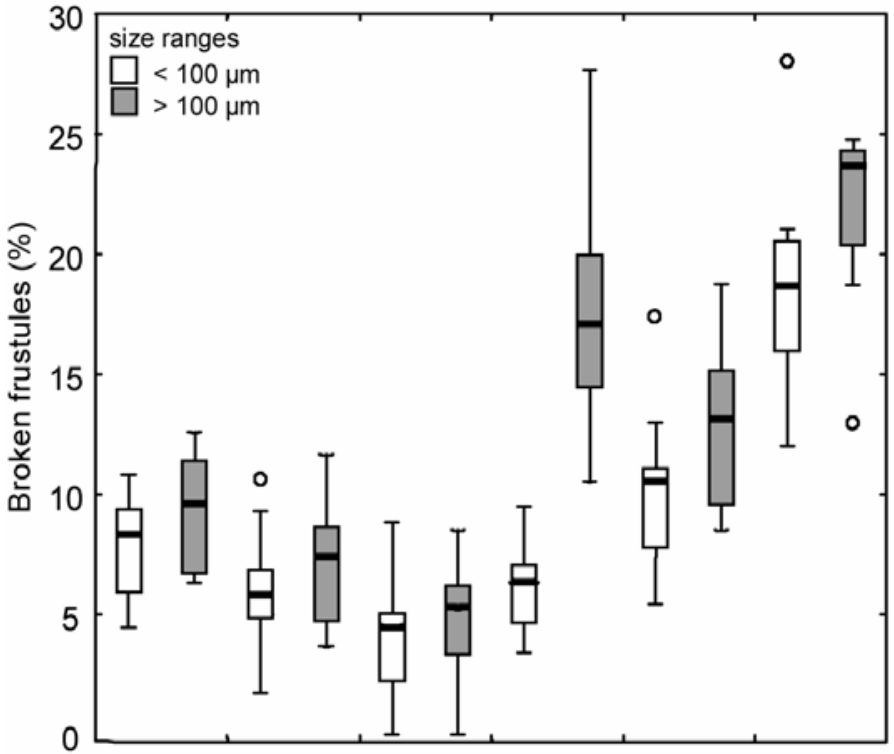

b)

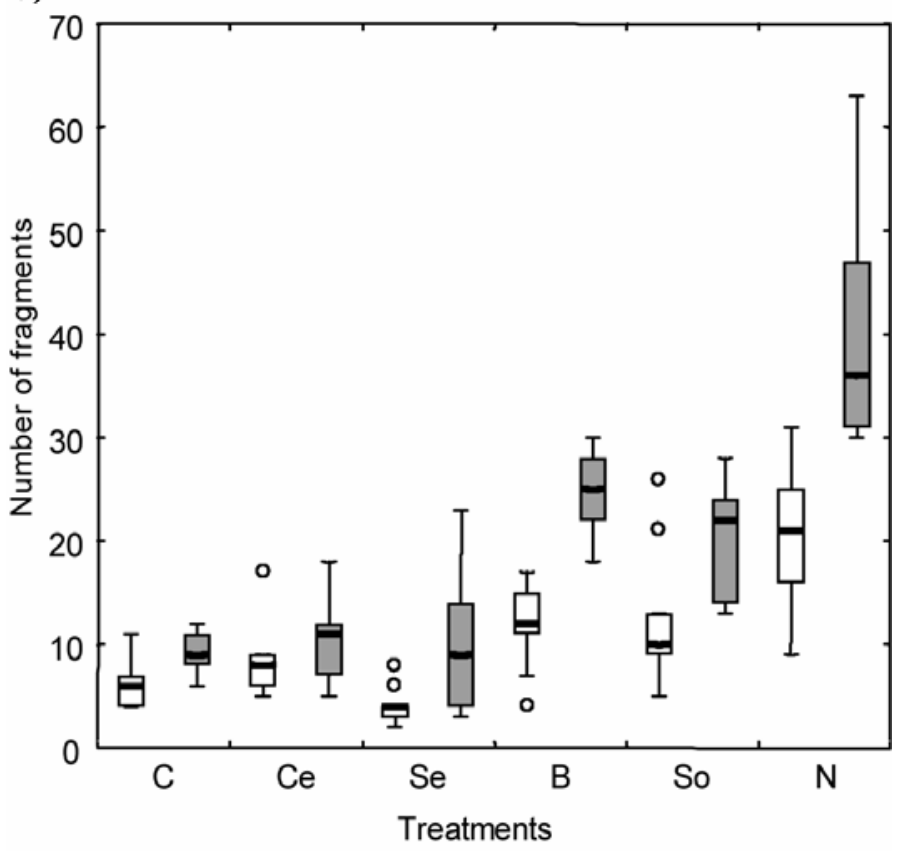

Fig. 2 Box and whisker plots showing (a) the percentages of broken frustules and (b) the number of fragments according to the size range of diatoms and to treatments with (C) control, $(\mathrm{Ce})$ centrifugation, $(\mathrm{Se})$ sedimentation, (B) boiling, (So) sonication, (N) Naphrax. Thick horizontal lines indicate medians, boxes the interquartile ranges and whiskers mark the range of data excluding outliers (open circles, $>1.5 \mathrm{x}$ interquartile range) $(\mathrm{n}=9)$.

For all variables, the $>100 \mu \mathrm{m}$ diatoms consistently exhibited higher values compared to the $<100 \mu \mathrm{m}$ class $(P$ $<0.008$ ). Effects of treatments on the number of contorted frustules were negligible. For both size classes, results from centrifugation, sedimentation and control did not differ from each other likely because of a large dispersion of values. Medians roughly fell between 5 and $10 \%$ of broken frustules and between 5 and 10 fragments. The Naphrax treatment concomitantly showed the highest median values of $18.7 \%$ and $23.7 \%$ of 
broken frustules (Fig. 2a) and of 21 and 36 fragments (Fig. 2b) respectively for $<100 \mu \mathrm{m}$ and $>100 \mu \mathrm{m}$ diatoms. For $<100 \mu \mathrm{m}$ diatoms, this treatment differed from all others $(P<0.03)$ except from sonication for broken frustules and differed from control and sedimentation values for the number of fragments $(P<0.001)$. Naphrax values for $>100 \mu \mathrm{m}$ diatoms did not differ from those of sonication and boiling but did so regarding all other treatments $(P<0.01)$. The $>100 \mu \mathrm{m}$ broken frustules and fragments undoubtedly weighted in the display of sonication and boiling values which became closer to the well separated Naphrax patch in the nMDS (ANOSIM $\mathrm{R}=0.55, P<0.01$, Fig. 3a) compared to that obtained for $<100 \mu \mathrm{m}$ diatoms (ANOSIM R $=0.44, P<0.01$, Fig. $3 b)$.
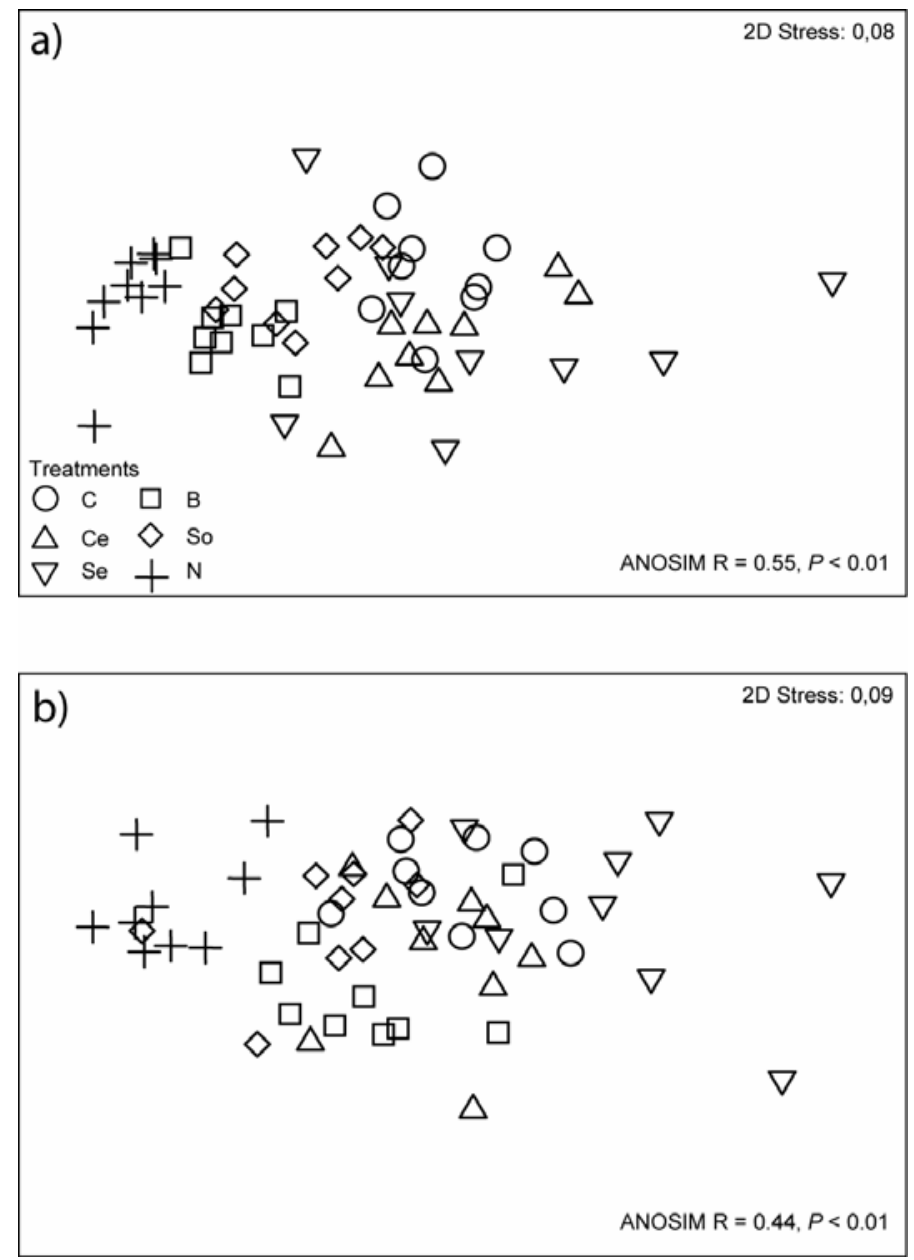

Fig. 3 nMDS ordinations calculated from percentages of broken and contorted frustules, and the number of fragments for (a) $>100 \mu \mathrm{m}$ and $(\mathrm{b})<100 \mu \mathrm{m}$ diatoms $(\mathrm{n}=9)$ with $(\mathrm{C})$ control, (Ce) centrifugation, (Se) sedimentation, (B) boiling, (So) sonication, (N) Naphrax.

Hydrogen peroxide and incineration exerted contrasted effects on the cleaning classes of frustules $(P<0.05$, Fig. 4). The median values of totally cleaned frustules were nearly two times higher for incineration $(73.4 \%)$ compared to the hydrogen peroxide treatment $(P=0.0004)$. Conversely, values from medium $(38.5 \%)$ and noncleaned $(13.0 \%)$ frustules for the hydrogen peroxide treatment were twice higher than those obtained for 
incineration $(P<0.0015)$. The occurrence of dissolved frustules was also by far higher for the hydrogen peroxide treatment $(7.3 \%)$ compared to incineration $(1.5 \%, P=0.0014)$. The higher overall number of valves and the twice higher number of fragments (44.0) counted for the hydrogen peroxide treatment compared to incineration weighted in the positive correlation observed between these variables $\left(\mathrm{r}^{2}=0.47, P<0.0016\right.$, Fig. 5).

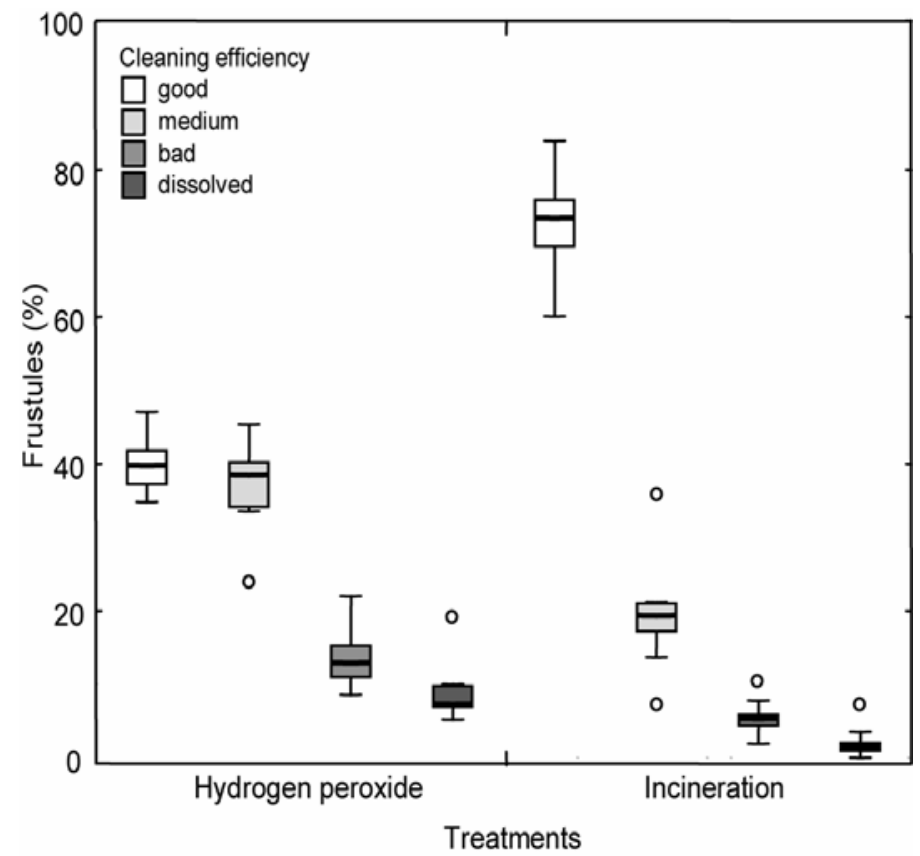

Fig. 4 Box and whisker plot showing the cleaning efficiency (\% per cleaning classes) of hydrogen peroxide and incineration on diatoms $(n=9)$. Thick horizontal lines indicate medians, boxes the interquartile ranges and whiskers mark the range of data excluding outliers (open circles, $>1.5 \mathrm{x}$ interquartile range).

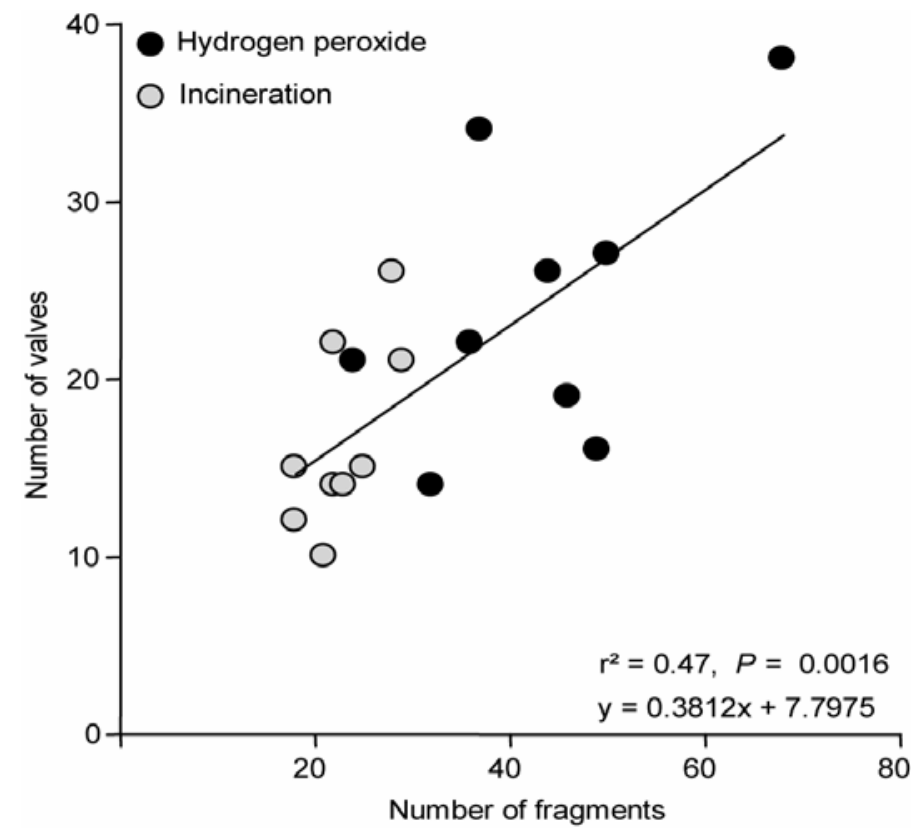

Fig. 5 Relationship between the total number of valves and the number of fragments according to cleaning treatments $(n=9)$. 


\section{Discussion}

This study allowed the quantification of cell losses occurring within samples of lightly silicified Mediterranean benthic diatoms by analysing the potential sources of mechanical and chemical stress occurring in the most commonly used processing techniques. Both for the assessments of the mechanical stress and the cleaning efficiency of frustules, samples exhibited large differences in the measured variables according to treatments even if we chose the gentlest methods reported in the literature (Tab. 1). For example, the number of washing cycles is usually greater, the centrifugation speed is faster than that we used (USGS 1987, Totti et al. 2007) and longer boiling durations ranging from 1 to $4 \mathrm{~h}$ are common when cleaning benthic diatoms (Muniz et al. 2011, Karsten et al. 2006). We also noticed that numerous studies suffer from a lack of methodological details (e.g. centrifugation speed and/or relative centrifugal force, sonication device) which could have been useful in our assessment of mechanical stress as well as for other diatomists who are looking for processing techniques.

We observed inter- and intra-sample variability in the measured parameters which may be considered as background losses due to the occurrence of already dead or grazed diatoms prior to process samples, to the initial harvesting and sieving steps, to the adhesion of cells on the wall of test tubes and by the variable intensity in the resuspension of material after each washing step (Throndsen 1978). Centrifugation speed and successive resuspensions at each concentration treatment (centrifugation and sedimentation) did not involve particular damage to diatoms as values were comparable to those from control. Our results are in agreement with those of Owen et al. (1978) and Blanco et al. (2008) who did not show significant effects of centrifugation on the preservation of frustules. In contrast, boiling, sonication and Naphrax mounting exerted pronounced mechanical stress on the physical integrity of frustules and especially on large forms $(>100 \mu \mathrm{m})$. The high surface areas of elongated pennate diatoms (mainly Nitzschia sp. and Licmophora sp.) may increase the risk of breakage compared to small broadly elliptical forms (Flower 1993) suggesting that subsamples could be exposed to different treatments according to the size range of diatoms. Although widely used in the cleaning of benthic diatoms (e.g. Taylor et al. 2005), the use of $\mathrm{H}_{2} \mathrm{O}_{2}$ or strong acids $\left(\mathrm{H}_{2} \mathrm{SO}_{4}, \mathrm{HNO}_{3}\right)$ and the enhancement of oxidation through boiling should be avoided for lightly silicified diatoms. Similarly, we neither recommend a cold use of these chemicals in addition to $\mathrm{KMnO}_{4}$ or $\mathrm{K}_{2} \mathrm{CR}_{2} \mathrm{O}_{7}$ because this produces vigorous bubbling and exothermic reactions (e.g. Hasle and Fryxell 1970) which may also have adverse effects on the preservation of frustules. Our results for $<100 \mu \mathrm{m}$ diatoms tend to support those of Hickman (1969) who did not find broken frustules even after 10 minutes of sonication of small freshwater epipsammic diatoms. However, for $>100 \mu \mathrm{m}$ diatoms, sonication should only be used to ease the dissociation of valves and identify some particular species 
(Battarbee et al. 2001). We also expected to find more contorted frustules following sonication but this parameter did not vary substantially according to treatments. Naphrax mounts involving boiling in a viscous medium and applying slight pressures on cover-slips led to the highest losses for both size ranges of diatoms. Accordingly, we recommend to make "dry mounts" (Hendey 1964, Round et al. 1990) or to use Pleurax which is known to provide good results for delicate diatoms and allows reference material to be stored for a long time (Reid 1978). However, the use of Pleurax is not common, may be time-consuming and may lead to cumulative losses of cells since serial alcohol dehydrations of samples are required before mounting (Hasle et al. 1996).

Incineration was the most efficient treatment to clean frustules in a non-selective way (i.e. lightly and more heavily silicified forms are indifferently and simultaneously cleaned of their organic contents) as opposed to the hydrogen peroxide method which left large proportions of non-cleaned and dissolved diatoms preventing further precise identification (Hart 1957, Hendey 1964, Ryves et al. 2006). We also found more valves and fragments in samples which underwent chemical digestion compared to those exposed to incineration. The use of hydrogen peroxide increases the dissociation of frustules but certainly has the drawback to increase the delicacy of valves. Accordingly, the combined use of centrifugations and chemical oxidation may have a negative impact on the preservation of diatoms. The incineration method is fast and simple and does not require using fume cupboard (Zoto et al. 1973). Although the focus of this study was not to test different setups for treatments, we recommend setting higher both the duration and the temperature (not over $538^{\circ} \mathrm{C}$ to prevent melting) of incineration to reach optimal results (USGS 1987). Nevertheless, in contrast to chemical digestion of organic matter, the incineration has the disadvantage of letting frustules intact without loosening colony and dissociating valves from frustules. This can be overcome by gently sieving sample through nylon nets and slowly dehydrating aliquots at room temperature to allow the settlement of frustules in valve rather than in girdle view (Blanco et al. 2008).

This work showed that some commonly used treatments may have major adverse effects on the preservation of Mediterranean benthic diatoms and that the successive use of sonication, boiling chemicals, centrifugations, and Naphrax may lead to high cumulative cell losses especially for large diatoms. This would undoubtedly have deep consequences on the taxonomic study of populations and thus in the environmental message delivered by diatoms. Accordingly, we suggest the following guidelines in order to process samples of Mediterranean benthic diatoms from oligotrophic areas: one cycle of 3 low speed centrifugations in order to remove preservative and dissolved salts, followed by the dehydration of an aliquot at room temperature and its incineration in a muffle furnace. Finally, a dry mount should be preferred to resin mounting. This procedure involving incineration allows to exclude one washing cycle and, thus indirectly, to minimise cell losses. Although the way to process 
The final publication is available at www.springerlink.com, Journal of Applied Phycology

samples may largely differ according to the environmental growing conditions of diatoms and to the intended taxonomic resolution of studies, we consider our stepwise quantification of treatment-induced cell losses as a robust and simple method to investigate lightly silicified populations and to improve already existing techniques for processing diatom samples.

\section{Acknowledgements}

We thank R. Biondo, C. Sénéchal and STARESO research station staff for field and laboratory assistance, MSc N. Sturaro and anonymous referees for their critical comments on this work. This study was funded by the ARCRapid Assessment for the marine Coastal Environment 05/10-333, by the FRS-FNRS (Belgian National Fund for Scientific Research) and the French Belgian community. S.V. is funded by a PhD grant from the ARC-RACE and G.L. is a Research Associate FRS-FNRS. This publication is MARE number 218.

\section{References}

Abrantes F, Gil I, Lopes C, Castro M (2005) Quantitative diatom analyses-a faster cleaning procedure. Deep Sea Res 52:189-198. doi:10.1016/j.dsr.2004.05.012

AFNOR NF EN 13946 (2003) Qualité de l'eau - Guide pour l'échantillonnage en routine et le prétraitement des diatomées benthiques de rivières. Saint Denis la Plaine

Agatz M, Asmus RM, Deventer B (1999) Structural changes in the benthic diatom community along a eutrophication gradient on a tidal flat. Helgol Mar Res 53:92-101. doi: 10.1007/PL00012144

Battarbee RW, Jones VJ, Flower RJ, Cameron NG, Bennion H, Carvalho L, Juggins S (2001) Diatoms. In Smol JP, Birks HJB, Last WM (eds) Tracking environmental change using lake sediments, volume 3: terrestrial, algal, and siliceous indicators, Kluwer Academic Publishers, Dordrecht, The Netherlands, pp 155-202

Blanco S, Álvarez I, Cejudo C (2008) A test on different aspects of diatom processing techniques. J Appl Phycol 20:445-450. doi: 10.1007/s10811-007-9292-2

Brandini FP, da Silva ET, Pellizzari FM, Fonseca ALO, Fernandes LF (2001) Production and biomass accumulation of periphytic diatoms growing on glass slides during a 1-year cycle in a subtropical estuarine environment (Bay of Paranaguá, southern Brazil). Mar Biol 138:163-171. doi: 10.1007/s002270000427

Busse S, Snoeijs P (2002) Gradient responses of diatom communities in the Bothnian Bay, northern Baltic Sea. Nov Hedw 74:501-525. doi:10.1127/0029-5035/2002/0074-0501 
The final publication is available at www.springerlink.com, Journal of Applied Phycology

Chessman BC, Bate N, Gell PA, Newall P (2007) A diatom species index for bioassessment of Australian rivers. Mar Freshwat Res 58, 542-557. doi : 10.1071/MF06220

Clarke KR, Gorley RN (2006) PRIMER v6: user manual/tutorial. PRIMER-E, Plymouth

Conley DJ, Kilham SS, Theriot E (1989) Differences in silica content between marine and freshwater diatoms. Limnol Oceanogr 34:205-213

Dela-Cruz J, Pritchard T, Gordon G, Ajani P (2006) The use of periphytic diatoms as a mean of assessing impacts of point source inorganic nutrient pollution in south-eastern Australia. Freshwat Biol 51:951-972. doi: $10.1111 / \mathrm{j} .1365-2427.2006 .01537 . \mathrm{x}$

Flower (1993) Diatom preservation: experiments and observations on dissolution and breakage in modern and fossil material. Hydrobiologia 269/270:473-484. doi: 10.1007/BF00028045

Gómez N, Licursi M (2001) The Pampean Diatom Index (IDP) for assessment of rivers and streams in Argentina. Aquat Ecol 35:173-181. doi: 10.1023/A:1011415209445

Gurrieri JT (1998) Distribution of metals in water and sediment and effects on aquatic biota in the upper Stillwater river basin, Montana. J Geochem explor 64:83-100. doi:10.1016/S0375-6742(98)00022-3

Hart TJ (1957) Notes on practical methods for the study of marine diatoms. J Mar Biol Assoc UK 36:593-597. doi: $10.1017 / \mathrm{S} 0025315400025868$

Hasle GR, Fryxell GA (1970) Diatoms: cleaning and mounting for light and electron microscopy. Trans Am Microsc Soc 89:469-474

Hasle GR, Syvertsen EE, Steidinger KA, Tangen K (1996) Identifying marine diatoms and dinoflagellates. In Tomas CR (ed) Identifying marine phytoplankton, Academic Press, pp 387-584

Hendey NI (1964) An introductory account of the smaller algae of British coastal waters: V. Bacillariophyceae (diatoms). Fishery Investigations Series IV. Her Majesty's Stationery Office: London XII

Hickman M (1969) Methods for determining the primary productivity of epipelic and epipsammic algal associations. Limnol Oceanogr 14:936-941

Hillebrand H, Sommer U (2000) Diversity of benthic microalgae in response to colonization time and eutrophication. Aquat. Bot. 67:221-236. doi:10.1016/S0304-3770(00)00088-7

Karsten U, Schumann R, Rothe S, Jung I, Medlin L (2006) Temperature and light requirements for growth of two diatom species (Bacillariophyceae) isolated from an Arctic macroalga. Polar Biol 29:476-486. doi: $10.1007 / \mathrm{s} 00300-005-0078-1$ 
The final publication is available at www.springerlink.com, Journal of Applied Phycology

Kelly MG (2003) Short term dynamics of diatoms in an upland stream and implications for monitoring eutrophication. Environ pollut 125:117-122. doi: 10.1016/S0269-7491(03)00075-7

Kelly MG, Cazaubon A, Coring E, Dell'Uomo A, Ector L, Goldsmith B, Guasch H, Hürlimann J, Jarlman A, Kawecka B, Kwandrans J, Laugaste R, Lindstrøm EA, Leitao M, Marvan P, Padisak J, Pipp E, Prygiel J, Rott E, Sabater S, Van Dam H, Vizinet J (1998) Recommendations for the routine sampling of diatoms for water quality assessments in Europe. J Appl Phycol 10:215-224. doi: 10.1023/A:1008033201227

Martin-Jézéquel V, Hildebrand M, Brzezinski MA (2000) Silicon metabolism in diatoms: implications for growth. J Phycol 36:821-840. doi: 10.1046/j.1529-8817.2000.00019.x

MacLulich JH (1987) Variations in the density and variety of intertidal epilithic microflora. Mar ecol prog ser 40:285-293

McBride TP (1988) Preparing random distributions of diatom valves on microscope slides. Limnol Oceanogr $33: 1627-1629$

Munda IM (2005) Seasonal fouling by diatoms on artificial substrata at different depths near Piran (Gulf of Trieste, Northern Adriatic). Acta adriat 46:137-157

Muniz P, Venturini N, Hutton M, Kandratavicius N, Pita A, Brugnoli E, Burone L, Garcia-Rodriguez F (2011) Ecosystem health of Montevideo coastal zone: a multi approach using some different benthic indicators to improve a ten-year-ago assessment. J Sea Res 65:38-50. doi:10.1016/j.seares.2010.07.001

Owen BB, Afzal M, Cody WR (1978) Staining preparations for phytoplankton and periphyton. Br Phycol J $13: 155-160$

Pan Y, Stevenson RJ, Hill BH, Herlihy AT (2000) Ecoregions and benthic diatom assemblages in Mid-Atlantic Highlands streams, USA. J North Am Benthol Soc 19:518-540

Pickett-Heaps JD (1998) A rapid, highly efficient method for collecting, fixing, and embedding planktonic and other small cells for electron microscopy. J Phycol 34:1088-1089. doi: 10.1046/j.1529-8817.1998.341088.x Prygiel J, Coste M (1993) The assessment of water quality in the Artois-Picardie water basin (France) by the use of diatom indices. Hydrobiologia 269/270:343-349. doi: 10.1007/BF00028033

Prygiel J, Coste M, Bukowska J (1999) Review of the major diatom-based techniques for the quality assessment of rivers - state of the art in Europe. In Prygiel J, Whitton BA, Bukowska J (eds) Use of algae for monitoring rivers III, Agence de l'Eau Artois-Picardie, Douai (France), pp 224-238

Reid FMH (1978) Permanent records. In Sournia A (ed) Phytoplankton Manual, UNESCO, Paris, pp 113-118 
The final publication is available at www.springerlink.com, Journal of Applied Phycology

Round FE, Crawford RM, Mann DG (1990) The diatoms: biology and morphology of the genera. Cambridge University Press, London

Ryves DB, Battarbee RW, Juggins S, Fritz SC, Anderson NJ (2006) Physical and chemical predictors of diatom dissolution in freshwater and saline lake sediments in North America and West Greenland. Limnol Oceanogr $51: 1355-1368$

Sabater S, Gregory SV, Sedell JR (1998) Community dynamics and metabolism of benthic algae colonizing wood and rock substrata in a forest stream. J Phycol 34: 561-567. doi: 10.1046/j.1529-8817.1998.340561.x

Taylor JC, De la Rey PA, Van Rensburg L (2005) Recommendations for the collection, preparation and enumeration of diatoms from riverine habitats for water quality monitoring in South Africa. Afr J Aquat Sci $30: 65-75$

Taylor JC, Prygiel J, Vosloo A, De la Rey PA, Van Rensburg L (2007) Can diatom-based pollution indices be used for biomonitoring in South Africa? A case study of the Crocodile West and Marico water management area. Hydrobiologia 592:455-464. doi: 10.1007/s10750-007-0788-1

Throndsen J (1978) Centrifugation. In Sournia A (ed) Phytoplankton Manual, UNESCO, Paris, pp 98 - 103

Totti C, Cucchiari E, De Stefano M, Pennesi C, Romagnoli T, Bavestrello G (2007) Seasonal variations of epilithic diatoms on different hard substrates in the northern Adriatic Sea. J Mar Biol Ass UK 87:649-658. doi: $10.1017 / \mathrm{S} 0025315407054665$

Underwood GJ, Phillips J, Saunders K (1998) Distribution of estuarine benthic diatom species along salinity and nutrient gradients. Eur J Phycol 33:173-183

US Geological Survey report (1987) Methods for collection and analysis of aquatic biological and microbiological samples. In Britton LJ, Greeson PE (eds) Techniques of water-resources investigations of the United States Geological Survey. Chapter A4, pp 127-150

Vermeulen S, Sturaro N, Gobert S, Bouquegneau JM, Lepoint G (2011) Potential early indicators of anthropogenically derived nutrients: a multiscale stable isotope analysis. Mar Ecol Prog Ser 422:9-22. doi:10.3354/meps08919

Zoto GA, Dillon DO, Schlichting HE (1973) A rapid method for clearing diatoms for taxonomic and ecological studies. Phycologia 12:69-70. doi: 10.2216/i0031-8884-12-1-69.1 